\title{
HUBUNGAN PENGETAHUAN IBU DAN HIGIENE PERORANGAN DENGAN KEJADIAN KECACINGAN PADA MURID TAMAN KANAK-KANAK IBNU HUSAIN SURABAYA
}

\section{Correlation between Mother Knowledge and Personal Hygiene with Helminthiasis among Students in Ibnu Husain Kindergarten Surabaya}

\author{
Ratna Kumala ${ }^{1}$, Ririh Yudhastuti ${ }^{2}$ \\ Departemen Kesehatan Lingkungan Fakultas Kesehatan Masyarakat \\ Universitas Airlangga Surabaya
}

\begin{abstract}
Helminthiasis is an environmental diasease and become a public health problem. Incidence is generally higher in densely populated areas with poor sanitation. Objective of this research was to analyze correlation between mother knowledge and personal hygiene with helminthiasis incidence among students in Ibnu Husain Kindergarten Surabaya. This research was observational with cross sectional design study. This research samples were 24 students of Ibnu Husain Kindergarten Surabaya and theirs mother. Primary data were collected by interview and laboratory test. Data was analyze by using coefficient Phi test to determine the correlation between variables. The result showed that 91,7\% mother has enough knowledge about helminthiasis problem in children. 79,2\% respondents have less of hand washing, 79,2\% respondents cut nails once a week, 75\% respondents used play on the ground and 54,2\% respondents have used footwear habit. The laboratory result showed that 16,7\% kindergarten student were positive with egg. At 79.2\% of respondents have the habit of washing hands is less, at 79.2\% of respondents have the habit to cut the nails once a week, for $75 \%$ of respondents have a habit of playing on the ground and of $45.8 \%$ of respondents have the habit of wearing footwear that is lacking. Genesis worm disease in $16.7 \%$ of respondents. There were strong enough correlation between cut nails $(r=0,321)$, palying on the ground $(r=0,258)$, and using footwear habit $(r=0,486)$ with helminthiasis incidence among students in Ibnu Husain Kindergarten Surabaya. It is suggested that the teachers should provide additional learning materials related to behavioral health and hygiene among students especially helminthiasis infection prevention behaviors.
\end{abstract}

Key words: helminthiasis, mother knowledge, personal hygiene 


\section{ABSTRAK}

Infeksi cacingan merupakan penyakit berbasis lingkungan yang masih menjadi masalah kesehatan masyarakat. Kejadian umumnya tinggi pada daerah dengan kepadatan penduduk yang tinggi dengan sanitasi yang buruk. Penelitian bertujuan untuk menganalisis hubungan antara pengetahuan ibu dan higiene perorangan dengan kejadian kecacingan pada murid Taman Kanak-kanak Ibnu Husain Surabaya. Penelitian menggunakan metode observasional dengan rancangan studi cross sectional. Sampel penelitian ini adalah murid dan ibu murid TK Ibnu Husain Surabaya sebanyak 24 orang. Pengambilan data primer dengan metode wawancara dan pemeriksaan laboratorium. Analisis data menggunakan uji korelasi phi untuk mengetahui kuat hubungan antar variabel. Hasil penelitian menunjukkan sebesar 91,7\% ibu memiliki pengetahuan yang cukup mengenai masalah cacingan pada anak. Sebesar $79,2 \%$ responden memiliki kebiasaan mencuci tangan yang kurang, sebesar 79,2\% responden memiliki kebiasaan memotong kuku seminggu sekali, sebesar $75 \%$ responden memiliki kebiasaan bermain di tanah dan sebesar 45,8\% responden memiliki kebiasaan memakai alas kaki yang kurang. Kejadian kecacingan pada responden sebesar 16,7\%. Terdapat 3 variabel yang memiliki kuat hubungan cukup dengan kejadian kecacingan pada murid TK Ibnu Husain Surabaya antara lain kebiasaan memotong kuku $(\mathrm{r}=0,321)$, kebiasaan bermain di tanah $(\mathrm{r}=0,258)$ dan kebiasaan memakai alas kaki $(\mathrm{r}=0,486)$. Disarankan kepada pihak TK Ibnu Husain Surabaya untuk memberikan materi belajar tambahan terkait perilaku hidup bersih dan sehat pada murid khususnya perilaku pencegahan infeksi cacingan.

\section{Kata kunci: kecacingan, pengetahuan ibu, higiene perorangan}

\section{PENDAHULUAN}

Kecacingan merupakan infestasi satu atau lebih cacing parasit usus yang terdiri dari golongan nematoda usus (WHO, 2016). Infeksi cacingan tersebar di seluruh dunia dan paling sering terjadi di negara berkembang dengan iklim tropis (Prasetyo, 2013). Hal tersebut disebabkan adanya faktor yang menunjang untuk hidup dan berkembangnya cacing seperti kondisi alam, iklim, suhu dan kelembapan (Natadisastra dan Ridad, 2009).

Indonesia termasuk salah satu negara beriklim tropis dan prevalensi cacingan umumnya masih tinggi terutama pada golongan penduduk kurang mampu dengan sanitasi yang buruk (Kemenkes RI, 2012). Rata-rata prevalensi cacingan di Indonesia mencapai lebih dari 28\% dengan tingkat yang berbeda di tiap daerahnya (Agustina, 2015). Sementara sebelumnya Kementerian Kesehatan pada tahun 2010 telah melakukan kebijakan opersional berupa kerjasama lintas program yang bertujuan untuk memutuskan rantai penularan dan menurunkan prevalensi cacingan menjadi $<20 \%$ pada tahun 2015 (Depkes RI, 2010).

Beberapa cacing usus yang sering ditemukan di Indonesia antara lain cacing gelang (Ascaris lumbricoides), cacing cambuk (Trichuris trichiura) dan cacing tambang (Necator americanus dan Ancylostoma duodenale) (Kemenkes RI, 2012). Cacing tersebut termasuk nematoda usus yang ditularkan melalui tanah atau Soil Transmitted Helminth (STH) karena cacing golongan ini membutuhkan tanah untuk pematangan dari bentuk non-infektif menjadi infektif (Natadisastra dan Ridad, 2009). Cacing tersebut akan tinggal di usus dan mengeluarkan ribuan telur setiap harinya dan keluar bersama feses manusia. Di daerah yang sanitasinya tidak memadai, telur tersebut dapat mencemari tanah (WHO, 2016).

Selain itu juga terdapat cacing kremi (Enterobius vermicularis) yang sering menginfeksi anak-anak (Widodo, 2013). Cacing ini tidak termasuk dalam golongan nematoda usus yang ditularkan melalui tanah atau Non-Soil Transmitted Helminth. Penularan infeksi cacing kremi dapat terjadi karena tertelannya telur melalui tangan yang terkontaminasi atau makanan (Ideham dan Suhintam, 2007).

Infeksi cacingan dapat mengenai siapa saja mulai dari bayi, balita, anak, remaja bahkan orang dewasa, namun infeksi pada anak sekolah adalah yang tertinggi dibandingkan golongan umur lainnya (Kemenkes RI, 2012). 
Tingginya angka cacingan pada anak usia sekolah dikarenakan mereka sering bermain atau kontak dengan tanah yang merupakan tempat tumbuh dan berkembangnya cacing perut (Rampengan, 2007).

Infeksi cacingan pada anak juga erat kaitannya dengan higiene perorangan. Anak yang masih belum mengerti tentang higiene perorangan akan lebih mudah terinfeksi kecacingan (Zulkoni, 2011). Penelitian Dwijayanti (2013) menunjukkan terdapat hubungan antara kebiasaan memakai alas kaki dan kebiasaan bermain di tanah dengan kejadian kecacingan pada murid SDN Klesem II Kecamatan Kebonagung Kabupaten Pacitan. Penelitian Nuary (2011) menunjukkan ada hubungan antara kebiasaan mencuci tangan dan kebiasaan memotong kuku dengan kejadian kecacingan pada siswa SDN Dinoyo 3 Kecamatan Lomokwaru Kota Malang.

Anak-anak rawan terinfeksi cacingan mengingat susahnya menjaga kebersihan perorangan mereka. Perilaku kebersihan anak sangat dipengaruhi oleh lingkungan sekitar termasuk orang tua dan keluarga yang mengasuhnya. Orang tua yang memiliki persepsi perilaku kebersihan yang benar diharapkan mampu menjaga dan memelihara kebersihan anaknya. Peran orang tua terutama ibu merupakan model atas tingkah laku bagi anak, termasuk dalam berperilaku hidup sehat khususnya perilaku pencegahan penyakit cacingan (Marlina dan Junus, 2012). Kurangnya pengetahuan dan kesadaran orang tua dalam memperhatikan kebersihan anak menyebabkan anak juga tidak memperhatikan kebersihan dirinya sendiri (Wong, 2009).

Kelurahan Sidotopo merupakan salah satu Kelurahan di Kota Surabaya dengan kepadatan penduduk yang tinggi dan tingkat sanitasi yang rendah. Akses penduduk di Kelurahan Sidotopo terhadap fasilitas sanitasi (jamban) yang layak masih sebesar 78,60\% (Dinas Kesehatan Kota Surabaya, 2015). Mayoritas penduduk di Kelurahan Sidotopo tingkat pendidikan terakhir adalah tamat SD. Taman Kanak-kanak Ibnu Husain merupakan salah satu Taman Kanak-kanak di Kelurahan Sidotopo yang memiliki jumlah murid cukup banyak. Jumlah murid tahun ajaran 2015/2016 sebanyak 73 murid. Sebagian besar murid berasal dari warga yang tinggal disekitarnya. Penelitian ini bertujuan untuk menganalisis kuat hubungan antara pengetahuan ibu dan higiene perorangan (kebiasaan mencuci tangan, memotong kuku, bermain di tanah dan memakai alas kaki) dengan kejadian kecacingan pada murid TK Ibnu Husain Surabaya.

\section{METODE PENELITIAN}

Penelitian menggunakan metode observasinal non-eksperimental dengan rancangan studi cross sectional. Populasi penelitian ini adalah seluruh murid dan ibu murid TK Ibnu Husain Surabaya tahun ajaran 2015/2016. Sampel penelitian diambil sebesar 24 orang yang terdiri dari 24 orang murid dan 24 ibu murid yang memenuhi kriteria inklusi.

Variabel bebas yang diteliti antara lain pengetahuan ibu dan kebersihan perorangan yang meliputi kebiasaan mencuci tangan, memotong kuku, bermain di tanah dan memakai alas kaki. Variabel terikat adalah kejadian kecacingan pada murid TK Ibnu Husain Surabaya.

Pengumpulan data primer dengan metode wawancara menggunakan kuesioner dan pemeriksaan laboratorium. Pemeriksaan laboratorium untuk mengetahui status kecacingan responden dengan melihat ada tidaknya telur cacing pada sampel feses responden. Pemeriksaan telur cacing menggunakan metode konsentrasi dengan larutan $\mathrm{NaCl}$. Sampel feses diambil oleh ibu responden dan dimasukkan kedalam pot sampel yang telah disediakan oleh peneliti. Sampel dikirim dan diperiksa oleh laboratorium terakreditasi di Surabaya. Penelitian ini telah mendapat persetujuan dari komisi etik.

Analisis dilakukan secara univariat untuk melihat distribusi frekuensi masing-masing variabel dan secara bivariat untuk melihat kuat hubungan antara variabel bebas dengan variabel terikat. Kuat hubungan antar variabel dianalisis menggunakan uji statistik Koefisien Phi.

\section{HASIL PENELITIAN DAN PEMBAHASAN}

Berdasarkan hasil wawancara diketahui pengetahuan ibu mengenai masalah cacingan 
pada anak dan higiene perorangan anak dapat dilihat pada Tabel 1.

Tabel 1. Hasil Wawancara Responden TK. Ibnu Husain Surabaya Tahun 2016

\begin{tabular}{lcc}
\hline \multicolumn{1}{c}{ Variabel } & Jumlah & \% \\
\hline Pengetahuan Ibu & 22 & \\
$\quad$ Cukup & 2 & 91,7 \\
$\quad$ Baik & & 8,3 \\
Higiene Perorangan Anak & 5 & \\
Kebiasaan mencuci tangan & 19 & 20,8 \\
$\quad$ Baik & & 79,2 \\
$\quad$ Kurang & 19 & 79,2 \\
Kebiasaan memotong kuku & 5 & 20,8 \\
$\quad$ Seminggu sekali & & 37,5 \\
$\quad$ Lebih dari seminggu sekali & 9 & 62,5 \\
Kebiasaan menggigit kuku & 15 & \\
$\quad$ Iya & & 25,0 \\
$\quad$ Tidak & 6 & 75,0 \\
Kebiasaan bermain di tanah & 18 & 70,8 \\
$\quad$ Tidak pernah & & 29,2 \\
$\quad$ Sering & 17 & 54,2 \\
Kontak tangan dengan tanah saat bermain & 7 & 45,8 \\
$\quad$ Iya & & \\
$\quad$ Tidak & 13 & \\
Kebiasaan memakai alas kaki & 11 & \\
$\quad$ Baik & & \\
Kurang & &
\end{tabular}

Pada Tabel 1 dapat dilihat bahwa sebesar 91,7\% ibu memiliki pengetahuan yang cukup mengenai masalah cacingan pada anak. Sebagian besar ibu responden sudah cukup mengetahui mengenai masalah cacingan pada anak seperti penyebab, gejala, dampak, dan cara pencegahannya.

Sebesar 79,2\% responden memiliki kebiasaan mencuci tangan yang kurang. Hanya sebagian kecil responden yang selalu mencuci tangan sebelum makan, setelah buang air besar dan setelah bermain menggunakan air dan sabun.

Sebesar 79,2\% responden memiliki kebiasaan memotong kuku yang baik. Sebagian besar responden sudah memotong kuku setiap seminggu sekali. Hal tersebut disebabkan karena adanya pemeriksaan kuku rutin yang dilakukan guru di sekolah setiap minggunya. Selain itu, diketahui sebesar $37,5 \%$ responden juga memiliki kebiasaan menggigit atau menghisap jari kedalam mulut.

Sebesar $75 \%$ responden memiliki kebiasaan bermain di tanah dimana 70,8\% diantaranya tangan mereka kontak langsung dengan tanah.

Sebesar 54,2\% responden sudah memiliki kebiasaan memakai alas kaki yang baik yaitu saat bermain di luar rumah, saat istirahat sekolah, saat berangkat dan pulang sekolah. Namun masih terdapat sebesar 45,8\% responden yang memiliki kebiasaan memakai alas kaki yang kurang.

Berdasarkan hasil pemeriksaan laboratorium, dapat dilihat kejadian kecacingan pada responden murid TK. Ibnu Husain Surabaya tahun 2016 pada Tabel 2. 
Tabel 2. Kejadian Kecacingan pada Responden Murid TK. Ibnu Husain Surabaya Tahun 2016

\begin{tabular}{lccl}
\hline Kejadian Kecacingan & Jumlah & \% & \multicolumn{1}{c}{ Keterangan } \\
\hline Positif & 4 & 16,7 & $-50 \%$ telur cacing \\
& & & $\begin{array}{l}\text { gelang Ascaris } \\
\text { lumbricoides }\end{array}$ \\
& & & $-50 \%$ telur cacing \\
& & & $\begin{array}{l}\text { kremi Enterobius } \\
\text { vermicularis }\end{array}$ \\
& & & \\
Negatif & 20 & 83,3 & \\
\hline Total & 24 & 100,0 & \\
\hline
\end{tabular}

Pada Tabel 2 dapat dilihat bahwa sebesar $16,7 \%$ responden murid positif ditemukan telur cacing dalam pemeriksaan fesesnya. Jenis telur cacing yang ditemukan antara lain $50 \%$ telur cacing gelang (Ascaris lumbricoides) dan 50\% telur cacing kremi (Enterobius vermicularis).

Infeksi cacing gelang umumnya bersifat kronis tanpa menimbulkan gejala klinis yang jelas dan dampak yang ditimbulkannya baru terlihat dalam jangka panjang (Kurniawan, 2011). Cacing gelang dalam tubuh manusia menghasilkan ribuan telur setiap harinya dan keluar bersama feses. Penularan cacing gelang dapat dengan cara tertelannya telur cacing melalui tangan, makanan atau minuman yang terkontaminasi oleh feses manusia (Natadisastra dan Ridad, 2009). Keberadaan cacing dalam tubuh manusia dapat menganggu absorbsi baik protein, lemak, karbohidrat maupun vitamin sehingga dapat terjadi malnutrisi (Prasetyo, 2013).
Infeksi cacing kremi (Enterobius vermicularis) merupakan infeksi cacingan yang mudah dikenali karena menimbulkan gejala yang khas. Penderita akan merasa gatal di daerah dubur pada malam hari dan cenderung untuk menggaruknya. Gejala tersebut juga menyebabkan gangguan tidur pada penderita. Penularan dapat melalui kontak langsung dengan tangan yang terkontaminasi telur cacing kremi maupun masuk tertelan lewat mulut (Prasetyo, 2013). Infeksi cacing ini mudah menular terutama pada orang terdekat dalam satu rumah maupun teman bermain. Tingkat higiene perorangan yang rendah dan penularan dari teman sekolah atau bermain merupakan faktor penyumbang angka infeksi cacing ini (Ideham dan Suhintam, 2007).

Hasil tabulasi silang dan analisis uji statistik Koefisien Phi antara pengetahuan ibu dan higiene perorangan dengan kejadian kecacingan pada murid TK. Ibnu Husain dapat dilihat pada Tabel 3.

Tabel 3. Tabulasi Silang Variabel Penelitian dengan Kejadian Kecacingan pada Responden Murid TK. Ibnu Husain Surabaya Tahun 2016

\begin{tabular}{|c|c|c|c|c|c|c|c|}
\hline \multirow{3}{*}{ Variabel } & \multicolumn{4}{|c|}{ Kejadian Kecacingan } & \multirow{3}{*}{ Jumlah } & \multirow{3}{*}{$\%$} & \multirow{3}{*}{$\mathbf{R}$} \\
\hline & \multicolumn{2}{|c|}{ Positif } & \multicolumn{2}{|c|}{ Negatif } & & & \\
\hline & n & $\%$ & $\mathbf{n}$ & $\%$ & & & \\
\hline \multicolumn{8}{|l|}{ Pengetahuan Ibu } \\
\hline Cukup & 4 & 16,7 & 18 & 75 & 22 & 91,7 & 0,135 \\
\hline Baik & 0 & 0,0 & 2 & 8,3 & 2 & 8,3 & \\
\hline \multicolumn{8}{|c|}{$\begin{array}{l}\text { Higiene Perorangan Anak } \\
\text { Kebiasaan mencuci } \\
\text { tangan }\end{array}$} \\
\hline Baik & 0 & 0,0 & 5 & 20,8 & 5 & 20,8 & 0,229 \\
\hline Kurang & 4 & 16,7 & 15 & 62,5 & 19 & 79,2 & \\
\hline $\begin{array}{l}\text { Kebiasaan memoto } \\
\text { kuku }\end{array}$ & & & & & & & \\
\hline
\end{tabular}




$\begin{array}{lccccccc}\text { Seminggu sekali } & 2 & 8,3 & 17 & 70,9 & 19 & 79,2 & 0,321 \\ \text { Lebih dari seminggu } & 2 & 8,3 & 3 & 12,5 & 5 & 20,8 & \\ \text { sekali } & & & & & & & \end{array}$

Kebiasaan bermain di tanah

$\begin{array}{lccccccc}\text { Tidak pernah } & 0 & 0,0 & 6 & 25,0 & 6 & 25,0 & 0,258 \\ \begin{array}{l}\text { Sering } \\ \text { biasaan memakai alas }\end{array} & 4 & 16,7 & 14 & 58,3 & 18 & 75,0 & \\ \text { Baik } & & & & & & & \\ \quad \text { Kurang } & 0 & 0,0 & 13 & 54,2 & 13 & 54,2 & 0,486 \\ & 4 & 16,7 & 7 & 29,1 & 11 & 45,8 & \\ \end{array}$

Responden yang positif ditemukan telur cacing memiliki ibu dengan tingkat pengetahuan yang cukup. Sedangkan pada ibu dengan tingkat pengetahuan yang baik tidak ditemukan responden yang positif cacingan. Hasil analisis uji korelasi phi, menunjukkan nilai koefisien korelasi sebesar 0,135 yang artinya pengetahuan ibu memiliki kuat hubungan yang sangat lemah dengan kejadian kecacingan pada murid.

Semua responden yang positif ditemukan telur cacing memiliki kebiasaan mencuci tangan yang kurang. Pada responden dengan kebiasaan mencuci tangan yang baik, tidak ditemukan positif telur cacing. Hasil analisis uji korelasi phi, menunjukkan nilai koefisien korelasi sebesar 0,229 yang artinya kebiasaan mencuci tangan memiliki kuat hubungan yang sangat lemah dengan kejadian kecacingan pada murid.

Sebesar 50\% dari responden yang positif ditemukan telur cacing memiliki kebiasaan memotong kuku lebih dari seminggu sekali dan sebagian lainnya memotong kuku seminggu sekali. Hasil analisis uji korelasi phi, menunjukkan nilai koefisien korelasi sebesar 0,321 yang artinya kebiasaan memotong kuku memiliki kuat hubungan yang cukup dengan kejadian kecacingan pada murid.

Semua responden yang positif ditemukan telur cacing memiliki kebiasaan sering bermain di tanah. Sedangkan pada responden yang tidak memiliki kebiasaan bermain di tanah, tidak ditemukan yang positif telur cacing. Hasil analisis uji korelasi phi, menunjukkan nilai koefisien korelasi sebesar 0,258 yang artinya kebiasaan bermain di tanah memiliki kuat hubungan yang cukup dengan kejadian kecacingan pada murid.

Semua responden yang positif ditemukan telur cacing memiliki kebiasaan memakai alas kaki yang kurang. Sedangkan pada responden yang memiliki kebiasaan memakai alas kaki yang baik, tidak ditemukan positif telur cacing. Hasil analisis uji korelasi phi, menunjukkan nilai koefisien korelasi sebesar 0,486 yang artinya kebiasaan memakai alas kaki memiliki kuat hubungan yang cukup dengan kejadian kecacingan pada murid.

Berdasarkan hasil pemeriksaan terhadap feses responden menunjukkan sebesar $16,7 \%$ positif ditemukan telur cacing. Jenis telur cacing yang ditemukan pada responden $50 \%$ diantaranya adalah cacing gelang (Ascaris lumbricoides) dan 50\% lainnya cacing kremi (Enterobius vermicularis).

Hasil wawancara dengan kepala sekolah TK. Ibnu Husain diketahui sudah ada kegiatan pemberian obat cacing pada murid yang merupakan program dari Dinas Kesehatan Kota Surabaya. Kegiatan dilakukan serempak bekerjasama dengan Puskesmas dan Posyandu setempat dengan sasaran kegiatan yaitu anak pra sekolah dan anak sekolah dasar di Kota Surabaya. Kegiatan pemberian obat cacing terakhir di TK. Ibnu Husain dilakukan pada bulan Agustus tahun 2015.

Masih ditemukannya murid yang positif telur cacing dapat disebabkan karena pemberian obat cacing terakhir sudah lebih dari 6 bulan yang lalu. Hasil wawancara kepada petugas puskesmas Sidotopo Surabaya diketahui kegiatan pemberian obat cacing hanya dilakukan setahun sekali. 
Mengingat bahwa obat cacing idealnya diminum setiap 6 bulan sekali, maka diharapkan kepada orang tua murid untuk memberikan obat cacing sendiri pada anak 6 bulan setelah pemberian obat cacing dari Puskesmas. Sementara sebagian besar ibu responden tidak mengetahui adanya kegiatan pemberian obat cacing pada anak di sekolah. Hal tersebut dikarenakan mayoritas murid selama sekolah tidak ditunggu oleh ibu mereka.

Hasil wawancara kepada ibu responden menunjukkan sebagian besar sudah memiliki pengetahuan yang cukup. Hanya sebagian kecil ibu responden yang memiliki pengetahuan yang baik mengenai masalah cacingan pada anak. Tingkat pengetahuan ibu dapat berhubungan dengan terjadinya infeksi cacingan pada anak. Ibu dengan pengetahuan yang baik tentang infeksi cacingan, dapat menjadi lebih protektif terhadap anaknya (Marlina dan Junus, 2012).

Hasil analisis menunjukkan pengetahuan ibu memiliki kuat hubungan yang sangat lemah dengan kejadian kecacingan pada murid. Sejalan dengan penelitian Limbanadi, dkk (2013) yang menyatakan bahwa tidak ada hubungan antara tingkat pengetahuan ibu dengan infestasi cacing pada siswa kelas IV, V dan VI di SD Negeri 47 Kota Manado. Berbeda dengan penelitian Ariska (2011) yang menyatakan bahwa ada hubungan antara tingkat pengetahuan ibu dengan kejadian infeksi cacing askariasis pada murid SDN 204/IV di Kelurahan Simpang IV Sipin Kota Jambi tahun 2011.

Pengetahuan ibu yang baik dapat mencegah terjadinya infeksi cacingan pada anak apabila diikuti juga dengan melakukan tindakan pencegahan. Berdasarkan hasil wawancara diketahui sebagian besar ibu responden tidak memberikan obat cacing pada anak dalam kurun waktu 6 bulan terakhir. Tidak dilakukannya tindakan pencegahan oleh ibu responden dapat menjadi salah satu penyebab masih terdapatnya murid yang positif telur cacing.

Hasil penelitian menunjukkan sebesar $79,2 \%$ responden memiliki kebiasaan mencuci tangan yang kurang, dimana
$16,7 \%$ diantaranya positif ditemukan telur cacing. Mencuci tangan adalah proses yang secara mekanis melepaskan kotoran dan debu dari kulit tangan dengan menggunakan sabun dan air bersih. Tangan adalah organ tubuh yang sering digunakan untuk mengambil dan memakan makanan (Ali, 2016). Kebiasaan makan dengan tangan tidak dicuci lebih dahulu meningkatkan penyebaran penyakit menular yang menyerang sistem pencernaan (Soedarto, 2009). Pencegahan kecacingan terutama ditujukan kepada kebersihan perorangan termasuk cuci tangan sesudah buang air besar dan sebelum makan (Natadisastra dan Ridad, 2009). Telur cacing dapat masuk kedalam tubuh lewat mulut melalui tangan atau makanan yang tersentuh tangan yang terkontaminasi (Ali, 2016).

Hasil analisis menunjukkan kebiasaan mencuci tangan memiliki hubungan yang sangat lemah dengan kejadian kecacingan pada murid. Hasil tersebut tidak sejalan dengan penelitian Fitri, dkk (2012) yang menyatakan bahwa faktor kebiasaan mencuci tangan paling berpengaruh dengan kejadian cacingan pada murid sekolah dasar di Kecamatan Angkola Timur Kebupaten Tapanuli Selatan tahun 2012. Hasil yang sama pada penelitian Muchlisah, dkk (2014) menyatakan bahwa terdapat hubungan antara kebiasaan cuci tangan pakai sabun dengan kejadian kecacingan di SD Athirah Bukit Baruga Makassar.

Kebiasaan mencuci tangan memiliki kuat hubungan yang sangat lemah dengan kejadian kecacingan dapat disebabkan karena sebagian besar responden memiliki kebiasaan mencuci tangan yang kurang dan hanya beberapa yang positif ditemukan telur cacing. Hal tersebut dapat dipengaruhi oleh hal lain yang tidak diteliti dalam penelitian ini seperti apakah responden makan disuapi oleh ibu dan menggunakan sendok atau tidak. Mengingat responden dalam penelitian ini adalah murid taman kanak-kanak yang mempunyai kemungkinan saat makan akan disuapi oleh ibunya.

Pada responden yang positif ditemukan telur cacing diketahui $50 \%$ diantaranya 
memiliki kebiasaan memotong kuku yang baik yakni seminggu sekali, sedangkan $50 \%$ lainnya memotong kuku lebih dari seminggu sekali. Diketahui sebesar 37,5\% responden memiliki kebiasaan menggigit atau menghisap jari kedalam mulut. Hasil analisis menunjukkan kebiasaan memotong kuku memiliki hubungan yang cukup dengan kejadian kecacingan pada murid. Sejalan dengan penelitian Ali, dkk (2016) yang menyatakan bahwa terdapat hubungan antara kebersihan kuku dengan kejadian kecacingan pada petani sayur di Kelurahan Maharatu Kecamatan Marpoyan Damai Kota Pekanbaru. Hasil yang sama dengan penelitian Fitri, dkk (2012) yang menyatakan bahwa kebersihan kuku merupakan salah satu variabel berpengaruh terhadap kejadian kecacingan pada murid sekolah dasar di Kecamatan Angkola Timur Kabupaten Tapanuli Selatan tahun 2012.

Faktor risiko lain yang berhubungan dengan infeksi kecacingan adalah kebersihan kuku karena kuku dapat menjadi perantara masuknya telur cacing ke dalam tubuh manusia (Winita dkk, 2012). Bibit penyakit dan telur cacing dapat berada pada tangan atau kuku yang kotor (Siswanto, 2010). Kuku yang panjang dapat menjadi tempat melekatnya berbagai kotoran maupun telur cacing yang kemudian dapat masuk ke dalam tubuh waktu mengkonsumsi makanan (Faridan dkk, 2013). Pencegahan kecacingan terutama ditujukan kepada kebersihan perorangan, salah satunya yaitu kuku harus dipotong pendek (Natadisastra dan Ridad, 2009).

Sebesar $75 \%$ responden memiliki kebiasaan bermain di tanah, dimana 16,7\% diantaranya positif ditemukan telur cacing. Diketahui pada responden yang memiliki kebiasaan bermain di tanah 70,8\% diantaranya tangan mereka kontak dengan tanah saat bermain. Hasil analisis menunjukkan kebiasaan bermain di tanah memiliki hubungan yang cukup dengan kejadian kecacingan pada murid. Hasil tersebut sejalan dengan penelitian Endriani, dkk (2011) yang menyatakan bahwa anak yang biasa bermain di tanah mempunyai kecenderungan infestasi cacingnya lebih tinggi.
Penyebaran infeksi cacingan dari feses manusia salah satunya melalui media tanah. Mempunyai kebiasaan bermain di tanah dapat meningkatkan risiko terjadinya infeksi cacingan pada anak. Cacing usus seperti cacing gelang (Ascaris lumbricoides) merupakan nematoda usus yang ditularkan melalui tanah (Natadisastra dan Ridad, 2009). Telur cacing yang berada di tanah dapat menempel pada tangan dan kuku anak saat bermain di tanah. Telur yang menempel pada tangan dapat masuk kedalam mulut apabila anak mempunyai perilaku kebersihan yang kurang seperti biasa memasukkan jari kedalam mulut atau tidak mencuci tangan sebelum makan.

Sebesar 54,2\% responden mempunyai kebiasaan memakai alas kaki yang baik yakni saat bermain diluar rumah, saat istirahat, berangkat dan pulang sekolah. Sedangkan $45, \% \%$ responden lainnya mempunyai kebiasaan memakai alas kaki yang kurang, dimana $16,7 \%$ diantaranya positif ditemukan telur cacing. Hasil analisis menunjukkan kebiasaan memakai alas kaki memiliki hubungan yang cukup dengan kejadian kecacingan pada murid. Sejalan dengan penelitian Muchlisah, dkk (2014) yang menunjukkan bahwa terdapat hubungan antara kebiasaan memakai alas kaki dengan kejadian kecacingan di SD Athirah Bukit Baruga Makassar. Hasil yang sama dengan penelitian Fitri, dkk (2012) yang menunjukkan bahwa kebiasaan memakai alas kaki merupakan salah satu variabel yang berpengaruh terhadap kejadian cacingan pada murid sekolah dasar di Kecamatan Angkola Timur Kabupaten Tapanuli Selatan tahun 2012.

Pada tanah yang tercemar tinja manusia dapat berada cacing maupun telur cacing didalamnya. Infeksi cacing usus yang hidup di tanah dapat terjadi dengan cara menembus kulit ketika bersentuhan langsung dengan tanah. Pemakaian alas kaki terutama saat bermain di tanah dapat mencegah terjadinya infeksi cacing yang masuk kedalam tubuh melalui kulit (Prasetyo, 2013). 


\section{SIMPULAN DAN SARAN}

Sebesar 91,7\% ibu responden memiliki pengetahuan yang cukup mengenai masalah cacingan pada anak. Sebesar 79,2\% responden murid mempunyai kebiasaan mencuci tangan yang kurang, 79,2\% responden memotong kuku seminggu sekali, $75 \%$ responden biasa bermain di tanah dan 54,2\% responden memiliki kebiasaan memakai alas kaki yang baik. Hasil pemeriksaan laboratorium menunjukkan sebesar 16,7\% responden positif ditemukan telur cacing. Pengetahuan ibu dan kebiasaan mencuci tangan mempunyai kuat hubungan yang sangat lemah dengan kejadian kecacingan pada murid TK. Ibnu Husain Surabaya tahun 2016. Sedangkan kebiasaan memotong kuku, bermain di tanah dan memakai alas kaki mempunyai kuat hubungan yang cukup dengan kejadian kecacingan pada murid TK. Ibnu Husain Surabaya tahun 2016.

Perlu dilakukan penyuluhan kepada ibu murid mengenai pentingnya pemberian obat cacing secara berkala setiap 6 bulan sekali untuk mencegah infeksi cacingan pada anak serta perlu diberikan materi belajar tambahan pada murid TK. Ibnu Husain Surabaya terkait perilaku hidup bersih dan sehat khususnya mengenai perilaku pencegahan infeksi cacingan.

\section{DAFTAR PUSTAKA}

Agustina, D. 2015. 'Cacingan' Bukan Lagi Penyakit Orang Kampung. Diakses dari http://www.cnnindonesia.com/gay a-hidup/20151105194633-25589764/cacingan-bukan-lagipenyakit-orang-kampung/

Ali, RU., Zulkarnaini., Affandi, D. 2016. Hubungan Personal Hygiene dan Sanitasi Lingkungan dengan Angka Kejadian Kecacingan (Soil Transmitted Helminth) pada Petani Sayur di Kelurahan Maharatu Kecamatan Marpoyan Damai Kota Pekanbaru. Dinamika Lingkungan Indonesia, 3(1): pp.24-32. Diakses dari http://ejournal.unri.ac.id/index.ph p/DL/article/download/3288/3199

Ariska, BM. 2011. Beberapa Faktor yang Berhubungan dengan Kejadian Infeksi Cacing Askariasis Lumbricoides pada Murid SDN 204/IV di Kelurahan Simpang IV Sipin Kota Jambi Tahun 2011. Skripsi. Universitas Andalas. Diakses dari http://repository.unand.ac.id/1730 3/1/beberapa_faktor_yang_berhub ungan_dengan_kejadian_infeksi_ cacing_askariasis_lumbricoides_ pada.pdf

Departemen Kesehatan Republik Indonesia. 2010. Penyakit Kecacingan Masih Dianggap Sepele. Diakses dari http://www.depkes.go.id/pdf.php? $\mathrm{id}=1135$

Dwijayanti, P. 2013. Hubungan Host, Agent, Environment dan Imunoglobulin E dengan Kejadian Kecacingan di SDN Klesem II Kecamatan Kebonagung Kabupaten Pacitan Tahun 2013. Skripsi. Universitas Airlangga Surabaya.

Endriani., Mifbakhdin., dan Sayono. 2011. Beberapa Faktor yang Berhubungan dengan Kejadian Kecacingan pada Anak Usia 1-4 Tahun. Jurnal Kesehatan Masyarakat Indonesia, 7(1): pp.22-35. Diakses dari http://jurnal.unimus.ac.id/index.ph $\mathrm{p} / \mathrm{jkmi} /$ article/download/585/637

Faridan, K., Marlinae, L., dan Alaudhah, N. 2013. Faktor-faktor yang berhubungan dengan kejadian kecacingan pada siswa Sekolah Dasar Negeri Cempaka 1 Kota Banjarbaru. Jurnal Epidemiologi dan Penyakit Bersumber Binatang, 4(3): pp. 121-127. Diakses dari http://ejournal.litbang.depkes.go.i $\mathrm{d} /$ index.php/buski/article/view/32 29

Fitri, J., Saam, Z., dan Hamidy, MY. 2012. Analisis Faktor-faktor Risiko Infeksi Kecacingan Murid Sekolah Dasar Di Kecamatan Angkola 
Timur Kabupaten Tapanuli Selatan Tahun 2012. Jurnal Ilmu Lingkungan, 6(2): pp. 146-161. Diakses

dari http://ejournal.unri.ac.id/inde x.php/jil/article/download/964/95 7

Ideham, B. dan Suhintam, P. 2007. Helmintologi Kedokteran.

Surabaya: Airlangga University Press.

Kementerian Kesehatan RI. 2012. Pedoman Pengendalian Kecacingan. Diakses dari http://perpustakaan.depkes.go.id:8 180/bitstream//123456789/1943/2 /BK212-493.pdf

Kurniawan, A. 2011. Infeksi Parasit: Dulu dan Masa Kini. Majalah Kedokteran Indonesia, 60(11). Diakses dari http://indonesia.digitaljournals.org /index.php/idnmed/article/viewFil e/747/752

Limbanadi, EM., Rattu, JA., dan Pitoi, M. 2013. Hubungan Antara Status Ekonomi, Tingkat Pendidikan dan Pengetahuan Ibu tentang Penyakit Kecacingan dengan Infestasi Cacing pada Siswa Kelas IV, V dan VI di SD Negeri 47 Kota Manado. Diakses dari http://fkm.unsrat.ac.id/wpcontent/uploads/2013/08/JurnalEka-M.Limbanadi091511075 kesling.pdf

Marlina, L dan Junus, W. 2012. Hubungan Pendidikan Formal, Pengetahuan Ibu dan Sosial Ekonomi terhadap Infeksi Soil Transmitted Helminths pada Anak Sekolah Dasar di Kecamatan Seluma Timur Kabupaten Seluma Bengkulu. Jurnal Ekologi Kesehatan [ejournal] 11(1): 33-39. Diakses dari http://ejournal.litbang.depkes.go.i d/index.php/jek/article/view/3824

Muchlisah, A., Manyullei, S., dan Birawida, AB. 2014. Hubungan Higiene Perorangan dengan Kejadian Kecacingan di SD Athirah Bukit Baruga Makassar. Diakses dari http://repository.unhas.ac.id/bitstr eam/handle/123456789/10580/ain un\%20muchlisah\%20k11110104. pdf? sequence $=1$

Natadisastra, D. dan Ridad, A. 2009. Parasitologi Kedokteran Ditinjau dari Organ Tubuh yang Diserang. Jakarta: Buku Kedoktertan EGC.

Nuary, AO. 2011. Hubungan antara Sanitasi

Perumahan dan Kebersihan

Perorangan dengan Kejadian

Penyakit Kecacingan pada Siswa

Sekolah Dasar Negeri Dinoyo 3

Kecamatan Lomokwaru Kota Malang. Skripsi. Universitas Airlangga Surabaya.

Prasetyo, H. 2013. Buku Ajar Parasitologi Kedokteran Parasit Usus. Jakarta: Sagung Seto.

Rampengan, TH. 2007. Penyakit Infeksi Tropik pada Anak Edisi 2. Jakarta: Buku Kedoktertan EGC.

Siswanto, Hadi. 2010. Pendidikan Kesehatan Anak Usia Dini. Yogyakarta: Pustaka Rihama.

Soedarto. 2009. Penyakit Menular di Indonesia. Jakarta: Sagung Seto.

World Health Organization. 2016. Soiltransmitted helminth infections. Diakses dari http://www.who.int/mediacentre/f actsheets/fs366/en/

Widodo, H. 2013. Parasitologi Kedokteran. Yogyakarta: D-Medika.

Winita, R., Mulyati., dan Astuty, H. 2012. Upaya Pemberantasan Kecacingan di Sekolah Dasar. Makara Kesehatan, 16(2), pp: 65-71. Diakses dari http://journal.ui.ac.id/index.php/h ealth/article/download/1631/1361

Wong, DL. 2009. Buku Ajar Keperawatan Pediatrik. Jakarta: Buku Kedoktertan EGC.

Zulkoni, A. 2011. Parasitologi: Untuk Keperawatan, Kesehatan Masyarakat dan Teknik Lingkungan. Yogyakarta: Nuha Medika. 